\begin{tabular}{cc}
\hline JPPIPA, Vol.3 No.1 2018 \\
Jurnal Penelitian Pendidikan IPA
\end{tabular}

\title{
MEMBANGUN KEMAMPUAN LITERASI SAINS SISWA MELALUI PEMBELAJARAN BERKONTEKS SOCIO-SCIENTIFIC ISSUES BERBANTUAN MEDIA WEBLOG
}

Oleh:

Ely Rohmawati ${ }^{1}$, Wahono Widodo ${ }^{2}$, Rudiana Agustini ${ }^{3}$

${ }^{1,2,3}$ Program Studi Pendidikan Sains, Pascasarjana, Universitas Negeri Surabaya, Indonesia

\begin{abstract}
Abstrak
Penelitian ini bertujuan untuk mendeskripsikan kemampuan literasi sains siswa dan respon siswa terhadap pembelajaran berkonteks Socio-Scientific Issues berbantuan media weblog. Jenis penelitian yang digunakan adalah penelitian deskriptif kuantitatif dengan rancangan penelitian one group pretest-postest design. Sampel yang digunakan dalam penelitian ini adalah siswa kelas VIII SMP Negeri 1 Sukodadi, semester ganjil tahun pelajaran 2016/2017. Hasil penelitian menunjukkan: Skor rata-rata kemampuan literasi sains siswa pada pre test 31,78 sedangkan post test 86.02 , ada peningkatan kemampuan literasi sains siswa rata-rata sebesar 54,24; dan Siswa merespon positif pembelajaran berkonteks socio-scientific issues berbantuan media blog dengan persentase $98,33 \%$. Berdasarkan hasil penelitian yang diperoleh, dapat disimpulkan bahwa proses pembelajaran berkonteks Socio-Scientific Issues berbantuan media weblog dapat melatihkan literasi sains siswa.
\end{abstract}

Kata Kunci : Literasi sains, Socio-Scientific Issues

\begin{abstract}
This research to describe the feasibility of learning, scientific literacy and students' response to Socio-Scientific Issues learning using weblog. This type of research is descriptive quantitative research design with one group pretest posstest design. The samples used in the study were students of class VIII SMP Negeri 1 Sukodadi in an odd semester of academic year $2016 / 2017$. The result showed, the average score of students science literacy ability on pre test 31,78 while post test 86.02 , there is improvement of literacy ability of student science average 54,24; And Students gave a positive response to Socio-Scientific Issues learning using weblog with a percentage of $98.33 \%$. Based on the result of this recent study, Socio-Scientific Issues learning using weblog to facilitate students scientific literacy skills.
\end{abstract}

Keywords: Science literacy, Socio-Scientific Issues

(C) 2018 Universitas Negeri Surabaya

\footnotetext{
Alamat Korespondensi:

Program Studi Pendidikan Sains,

Pascasarjana, Universitas Negeri Surabaya,

Surabaya 60231, Indonesia

Email: wahonowidodo@unesa.ac.id
}

p-ISSN: 2527-7537

e-ISSN: 2549-2209 


\section{PENDAHULUAN}

Pembelajaran IPA merupakan sesuatu yang harus dilakukan oleh siswa bukan sesuatu yang dilakukan terhadap siswa. Pembelajaran IPA yang didasarkan pada standar isi akan membentuk siswa yang memiliki bekal ilmu pengetahuan, standar proses membentuk siswa yang memiliki keterampilan ilmiah, keterampilan berpikir dan strategi berpikir, standar inkuiri ilmiah akan membentuk siswa yang mampu berpikir kritis dan kreatif.

Penggolongan IPA secara umum terbagi menjadi tiga ilmu dasar, yaitu fisika, biologi, dan kimia. Ilmu-ilmu tersebut lahir dan berkembang melalui langkah-langkah observasi, perumusan masalah, penyusunan hipotesis, eksperimen, penarikan kesimpulan, dan diakhiri dengan penemuan konsep atau teori. IPA pada hakikatnya merupakan suatu produk, proses, dan aplikasi. IPA sebagai produk terdiri dari hukum, prinsip, prosedur, teori, konsep, fakta, dan informasi, sedangkan sebagai suatu proses, IPA merupakan proses yang dipergunakan untuk mempelajari objek studi, menemukan dan mengembangkan produk-produk sains dan sebagai aplikasi.

Perkembangan abad 21 ditandai oleh semakin bertautnya ilmu dan teknologi, sehingga sinergi di antaranya menjadi cepat. Berbagai upaya dalam rangka peningkatan mutu pendidikan pun senantiasa dilakukan, disesuaikan dengan perkembangan situasi dan kondisi, serta era yang terjadi (BSNP, 2010). Pendidikan abad ke-21 tidak hanya memperhatikan materi bidang kajian (core subjects) sebagaimana terjadi pada abad sebelumnya, tetapi juga memberikan penekanan pada kecakapan hidup (life skills), keterampilan belajar dan berpikir (learning \& thinking skills), literasi dalam teknologi informasi dan komunikasi (ICT Literacy) (Purwanti, 2013).

Kurikulum 2013 mengisyaratkan siswa harus memiliki kemampuan yang lebih produktif, kratif, inovatif, dan afektif maka dibutuhkan proses pembelajaran yang mendukung kreatifitasnya. Kurikulum ini menuntun guru memiliki kreativitas dan pola berpikir tingkat tinggi (Higher Order Thinking) dalam pelaksanaan IPA didalam kelas. Sehingga bisa meningkatkan pengetahuan, sikap, dan keterampilan serta proses pembelajaran yang lebih berpusat pada siswa (Student centered active learning).

Kurikulum $2013 \quad$ mengakomodasi pengembangan literasi sains bagi siswa. Literasi sains adalah kemampuan menggunakan ilmu pengetahuan, mengidentifikasi pertanyaan dan menarik kesimpulan berdasarkan bukti-bukti untuk membuat keputusan tentang alam dan membuat perubahan melalui aktivitas manusia (OECD, 2013:11). Literasi sains bukan hanya pemahaman terhadap pengetahuan saja, melainkan juga menyangkut pemahaman terhadap berbagai aspek proses sains, serta kemampuan mengaplikasikan pengetahuan dan proses sains dalam situasi nyata yang dihadapi siswa, baik secara personal, sosial, maupun global (Deboer, 2000).

Hasil Studi PISA menunjukkan bahwa tingkat literasi sains siswa indonesia masih rendah dan di bawah rata-rata OECD. Pengukuran literasi sains yang terakhir dilakukan pada tahun 2015 menunjukkan bahwa rata-rata nilai literasi sains siswa indonesia adalah 403. Pengukuran literasi sains tersebut meskipun mengalami peningkatan tetapi masih rendah dibanding rerata OECD (OECD, 2015). Hasil tersebut menunjukkan bahwa siswa Indonesia masih kesulitan membuat hubungan antara konsep sains dan fenomena dalam kehidupan sehari-hari.

Berdasarkan hasil wawancara guru IPA di SMPN 1 Sukodadi menunjukkan bahwa kegiatan pembelajaran yang dilaksanakan selama ini kurang berpusat pada siswa sehingga siswa sulit memahami konsep yang dipelajarinya, pencapaian hasil pembelajaran hanya berkisar pada tingkat mengetahui berupa hafalan dan kurang mampu menentukan dan merumuskan masalah-masalah dalam kehidupan nyata yang berhubungan dengan konsep yang dimiliki. Proses pembelajaran yang dilakukan selama ini juga masih kurang memanfaatkan media pembelajaran, seperti media digital ( komputer dan internet)

Fakta lain menunjukkan bahwa hasil belajar sebagian besar siswa masih belum mencapai KKM (Kriteria Ketuntasan Minimal) pada sub materi zat aditif. Hal ini diperkuat dengan hasil pra penelitian tes literasi sains pada materi zat aditif dalam makanan terhadap 20 siswa menunjukkan bahwa sebanyak $65 \%$ siswa berada di level 1,25\% siswa berada di level 2 dan $10 \%$ berada di level 3. Siswa yang mendapatkan nilai dibawah KKM sebesar $90 \%$.

Salah satu materi dalam pembelajaran IPA di SMP adalah zat aditif dalam makanan. Materi zat aditif dalam makanan adalah salah satu materi yang berkaitan erat dengan kehidupan sehari-hari sehingga banyak isu-isu sains yang dapat diangkat untuk dibahas dalam kegiatan belajar mengajar. Salah satu isu tersebut adalah maraknya penyalahgunaan zat aditif dalam makanan di kalangan masyarakat yang menimbulkan dampak buruk pada kesehatan. Penggunaan zat aditif yang tidak sewajarnya akhir-akhir ini telah menjadi sorotan masyarakat umum dan muncul sebagai Socio-Scientific Issues (SSI). SSI yang diterapkan dalam pembelajaran sains diharapkan dapat memberikan pengalaman belajar yang lebih bermakna. Hasil penelusuran menunjukkan bahwa penelitian yang berkaitan dengan penggunaan SSI 
dalam pembelajaran sains masih terbatas, SSI terkait lingkungan (Zo'bi, 2014) dan isu bioteknologi pernah digunakan untuk mengembangkan keterampilan argumentasi dalam pembelajaran sains.

Pembelajaran materi zat aditif dalam makanan yang hanya disampaikan dengan metode ceramah menyebabkan siswa kurang antusias dan kurang terlibat aktif dalam pembelajaran sehingga siswa kurang tanggap dalam memecahkan masalah berkaitan dengan materi zat aditif dalam makanan yang biasanya siswa konsumsi hampir setiap hari. Hal ini juga terjadi karena kurangnya alokasi waktu yang disediakan dalam kegiatan belajar mengajar dan sumber belajar yang terbatas. Siswa hanya belajar dari buku teks sehingga hasil belajar siswa rendah, wawasan siswa kurang berkembang dan siswa kurang berminat dalam mengikuti pelajaran. Upaya untuk meningkatkan hasil belajar dan interaksi antara guru dengan siswa atau antar sesama siswa salah satunya dengan pembelajaran yang difasilitasi dengan teknologi agar dapat dilakukan kapanpun dan dimanapun selama memiliki akses internet. Penggunaan media pembelajaran berbasis web diharapkan dapat mengatasi kendala - kendala dalam pembelajaran materi zat aditif dalam makanan.

Media pembelajaran sebagai salah satu komponen pembelajaran yang mempunyai peranan penting dalam kegiatan belajar mengajar. Salah satu media internet yang dimanfaatkan dalam pendidikan/pembelajaran adalah media blog. Menurut Herlanti (2012) bahwa pembelajaran dengan menggunakan Weblog yang dikembangkan terbukti efektif meningkatkan literasi sains. Melalui e-learning materi pembelajaran dapat diakses kapan saja dan dimana saja, disamping itu materi pembelajaran dapat diperkaya dengan cepat dan dapat diperbaharui (di-update) oleh pembelajar.

Beberapa hal yang mendasari penulis memanfaatkan media blog untuk melatihkan literasi sains siswa di SMP Negeri 1 Sukodadi didukung dengan adanya fasilitas laboratorium komputer dan wifi yang dapat menunjang dalam kegiatan pembelajaran. Weblog yang digunakan memiliki keunggulan antara lain: (1) struktur yang sistematis, (2) fiture design yang disesuaikan dengan karakteristik pebelajar, (3) ketersediaan materi yang disesuaikan dengan silabus dan RPP, (4) pemilihan hosting yang mudah diakses, (5) kemudahan dalam mengakses di semua jenis web browser, (5) ketersediaan link-link pendukung materi dalam weblog (Heni, 2008).

Strategi pembelajaran yang potensial untuk diterapkan adalah pembelajaran berkonteks socioscientific issues (SSI). Socio-scientific issues (SSI) tidak hanya berperan dalam memenuhi kontekstualitas pembelajaran sains. SSI adalah strategi yang bertujuan untuk menstimulasi perkembangan intelektual, moral dan etika, serta kesadaran perihal hubungan antara sains dengan kehidupan sosial (Nuangchalerm, 2010). Socioscientific issues (SSI) merupakan strategi pembelajaran yang menyajikan materi sains dalam konteks isu-isu sosial dengan melibatkan komponen moral dan etika. Socio-scientific issues (SSI) merupakan salah satu strategi yang potensial untuk diterapkan dan merupakan pengajaran yang efektif yang mendukung tujuan literasi sains dan perkembangan karakter moral siswa. Socioscientific issues (SSI) merupakan representasi isuisu atau persoalan-persoalan dalam kehidupan sosial yang secara konseptual berkaitan erat dengan sains.

Hasil penelitian yang dilakukan oleh Fowler, Zeidler, dan Sadler (dalam Zeidler \& Nichols, 2009, p.54) yang menyatakan bahwa pembelajaran berkonteks SSI dapat meningkatkan penalaran moral siswa, sehingga memberikan kontribusi bagi perkembangan moral siswa secara keseluruhan. Nuangchalernm (2010) menunjukkan diskusi Socio-scientific issues (SSI) berhubungan dengan literasi sains. Peningkatan literasi sains dengan penggunaan konteks Socio-scientific issues (SSI) didukung oleh yang menyatakan pembelajaran berkonteks Socio-scientific issues (SSI) dapat meningkatkan literasi sains dan dapat membantu siswa menjadi warga negara yang bertanggung jawab, karena pembelajaran berkonteks SSI mempersiapkan siswa untuk mengkaji dan meneliti masalah sosial yang berhubungan dengan sains. Socio-scientific issues (SSI) penting dalam bidang pendidikan sains karena merupakan komponen penting dalam literasi sains.

Berdasarkan uraian diatas, maka peneliti melakukan penelitian mengenai"Efektivitas Pembelajaran berkonteks Socio-scientific issues (SSI) dengan Berbantuan Media Weblog untuk Melatihkan Literasi Sains Siswa". Penelitian ini bertujuan untuk mendeskripsikan kemampuan literasi sains siswa dan respon siswa terhadap pembelajaran berkonteks Socio-Scientific Issues berbantuan media weblog di kelas VIII SMP.

\section{METODE}

Jenis penelitian ini adalah penelitian deskriptif kuantitatif. Penelitian ini ditujukan untuk mendeskripsikan ada tidaknya akibat dari suatu perlakuan yang diberikan pada subjek penelitian. Rancangan penelitian yang dipakai adalah One Group pretest posttest design.

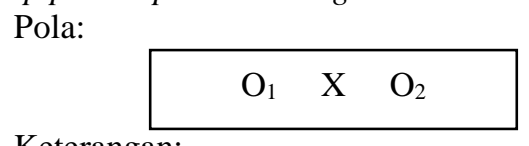

Keterangan: 


$$
\begin{gathered}
\mathrm{O}_{1}=\text { pretest } \text { sebelum diberikan perlakuan } \\
\mathrm{X}=\text { kelas dengan pembelajaran berkonteks } \\
\quad \text { Socio-Scientific Issues }
\end{gathered}
$$

Sasaran penelitian ini diujicobakan pada 12 siswa kelas VIII di SMP Negeri 1 Sukodadi Lamongan semester ganjil tahun ajaran 2016/2017.

Teknik pengumpulan data yang digunakan meliputi: (1) metode observasi untuk memperoleh data keterlaksanaan pembelajaran; (2) metode tes yang digunakan untuk mengetahui perkembangan kemampuan literasi sains siswa sebelum dan sesudah pembelajaran.; (3) metode angket untuk mengetahui respon siswa setelah mengikuti proses pembelajaran.

Teknik analisis data dilakukan secara deskriptif kualitatif yaitu dengan menghitung hasil pengamatan(diamati oleh pengamat), kemudian akan dicari presentase mengenai keterlaksanaan tahapan-tahapan dalam pembelajaran yang dilakukan guru selama proses pembelajaran berlangsung. Analisis hasil tes literasi sains diperoleh berdasarkan nilai ketuntasan literasi sains. Keberhasilan seorang siswa dapat dikatakan tuntas apabila nilai yang diperolehsiswa mencapai Kriteria Ketuntasan Minimum (KKM) disekolah yaitu 75. Indikator dikatakan tuntas apabila $\geq 75 \%$ siswa mencapai ketuntasan indikator. Ketuntasan individu ditetapkan dengan capaian optimun minimal 75 berdasarkan KKM yang dianalisis peneliti dengan mengacu Permendikbud No. 23 Tahun 2016. Analisis dari hasil angket respon siswa dianalisis secara diskriptif kuantitatif untuk mengetahui pendapat peserta didik terhadap perangkat pembelajaran yang dikembangkan.

\section{HASIL DAN PEMBAHASAN}

Sebelum proses pembelajaran dimulai, dilakukan pretest untuk mengukur kemampuan awal literasi sains siswa kemudian dilakukan pembelajran. Sedangkan posttest digunakan untuk mengetahui capaian literasi sains siswa setelah diterapkan pembelajaran berkonteks SocioScientific Issues pada materi zat aditif dalam maknan. Hasil keterlaksanaan pembelajaran disajikan dalam Gambar 1.

Pengamatan keterlaksanaan pembelajaran dilakukan oleh dua orang pengamat selama tiga kali pertemuan. Berdasarkan grafik diatas menunjukkan bahwa keterlaksanaan pembelajaran berada dalam kategori sangat baik dengan penilaian keterlaksanaan pembelajaran pada pertemuan 1, pertemuan 2 dan pertemuan 3 berturut-turut adalah 3,78; 3,95; dan 3,96. Pendiskripsian skor disesuaikan dengan diskripsi yaitu rentang antara 3,5-4,00 didiskripsikan sangat baik. Selain itu nilai percentage agreement keterlaksanaan pembelajaran berada $\geq 75 \%$ yaitu $97,56 \%$, hal ini menunjukkan bahwa instrumen keterlaksanaan pembelajaran yang telah disusun memiliki konsistensi atau keajegan dalam mengukur keterlaksanaan pembelajaran selama proses pembelajaran.

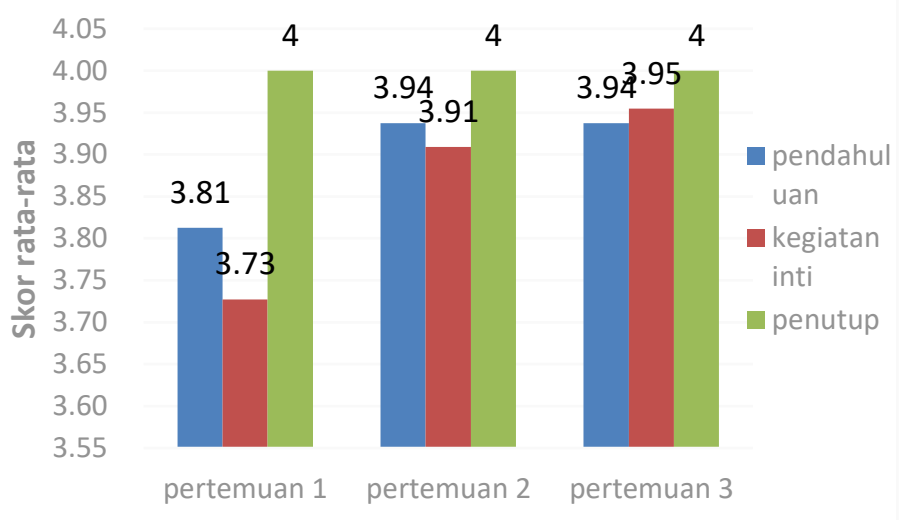

Gambar 1. Grafik Keterlaksanaan Pembelajaran

Socio-scientific Issues (SSI) adalah strategi yang diimplementasikan dalam proses pembelajaran yang berupaya mendekatkan siswa dengan persoalan-persoalan sains secara kontekstual melalui isu-isu sosial yang bisa ditemukan dalam kehidupan sehari-hari. Manfaat dikemukakannya isu atau masalah pada awal pembelajaran, dapat mengundang pro dan kontra sehingga mengharuskan siswa untuk berpikir dan menganalis isu tersebut. Proses pembelajaran melibatkan guru sebagai pembimbing dalam melaksanakan kegiatan pembelajaran. Pada pertemuan pertama guru lebih banyak berperan membantu siswa dalam menyelesaikan kegiatan pada lembar kegiatan siswa, dan frekuensi bantuan guru berkurang pada pertemuan berikutnya. Guru berperan sebagai scaffolding. Guru memberikan scaffolding erat kaitannya dengan gagazan zone of proximal development. Selama sesi pengajaran, orang lebih ahli (guru) menyesuaikan jumlah bimbingannya dengan level kinerja siswa yang telah tercapai.

Tes kemampuan literasi sains siswa diberikan sebelum dan sesudah dilaksanakan proses kegiatan belajar mengajar. Pemberian tes sebelum kegiatan belajar mengajar bertujuan untuk mengetahui literasi sains awal siswa dan pemberian tes sesudah kegiatan belajar mengajar bertujuan untuk mengetahui peningkatan literasi sains siswa setelah menerima pembelajaran.

Hasil ketercapaian literasi sains siswa dapat dilihat pada Gambar 2 berikut: 


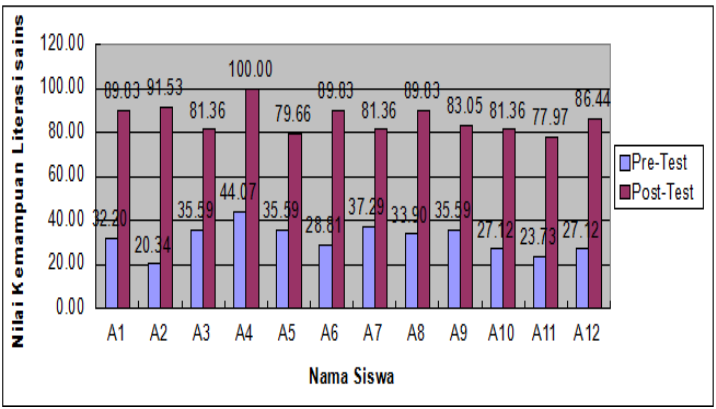

Gambar 2. Hasil Ketercapaian Literasi Sains

Berdasarkan grafik diatas menunjukkan bahwa pada saat pre test tidak seorangpun siswa yang tuntas. Setelah dilaksanakan pembelajaran berkonteks socio-scientific issues dengan berbantuan media weblog, siswa tuntas semua. Siswa dikatakan tuntas jika siswa memperoleh nilai sama dengan atau lebih dari KKM yaitu 75. Jumlah rata-rata kemampuan literasi sains siswa pada pre test 31,78 , sedangkan post test 86,02 , jadi ada peningkatan kemampuan literasi sains siswa ratarata sebesar 54,24.

Data yang diperoleh diolah untuk menganalisi indikator kompetensi literasi sains yang telah

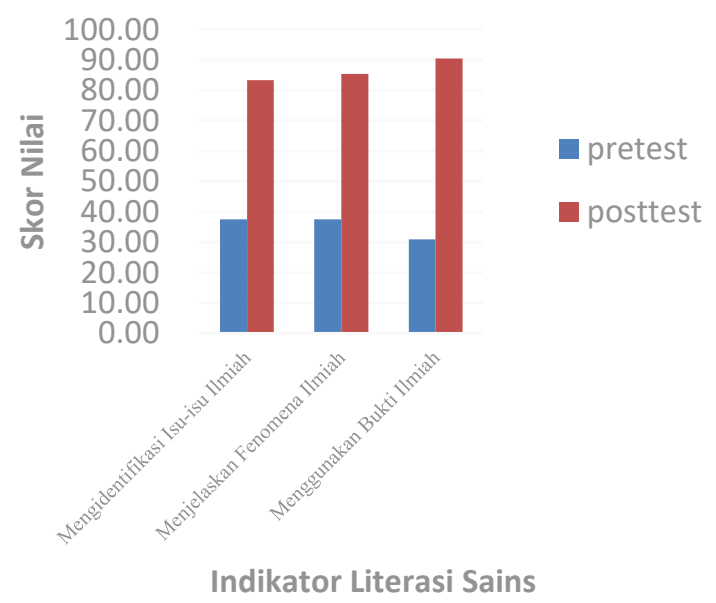

dikembangkan. Hasil perhitungan analisis indikator literasi sains dapat dilihat Gambar 3.

Gambar 3. Analisis Indikator Literasi Sains

Berdasarkan grafik diatas menunjukkan bahwa sebelum diterapkannya perangkat pembelajaran berkonteks Socio-Scientific Issues dalam proses pembelajaran rerata skor masing-masing indikator berkisar 30,95 sampai 37,50 dan setelah diterapkannya perangkat pembelajaran berkonteks Socio-Scientific Issues dalam proses pembelajaran rerata skor masing-masing indikator mencapai 83,33 sampai 90,48 .

Berdasarkan hal tersebut, dapat dikatakan bahwa pembelajaran berkonteks socio-scientific issues dengan berbantuan weblog dapat melatihkan literasi sains dan memfasilitasi siswa untuk mencapai kompetensi literasi sains. Isu-isu yang disajikan dalam proses pembelajaran, merupakan isu-isu yang ada di sekitar siswa dan sangat berkaitan dengan kehidupan nyata sehingga memotivasi siswa untuk memaknai materi pelajaran yang sedang dipelajarinya.

Menurut pembelajaran dengan menggunakan SSI akan meningkatkan kemampuan siswa dalam membuat keputusan terkait isu sosial yang kontroversial. menyatakan bahwa selain kemampuan intelektual, seseorang dikatakan berliterasi sains apabila juga memiliki kemampuan berpikir tingkat tinggi, sosial, dan interdisipliner.

Literasi sains tidak hanya berkaitan dengan aspek penguasaan ilmu, tetapi juga bersinggungan dengan aspek sosial. Menurut PISA literasi sains dapat didefinisikan sebagai kemampuan menggunakan pengetahuan sains, mengidentifikasi pertanyaan, dan menarik kesimpulan terhadap bukti-bukti, dalam rangka memahami serta membuat keputusan berkenaan dengan alam dan perubahan yang dilakukan terhadap alam melalui aktivitas manusia.

Penilaian kemampuan literasi sains siswa didasarkan pada kompetensi ilmiah yang meliputi mengidentifikasi isu-isu ilmiah, menjelaskan fenomena ilmiah, dan menggunakan bukti ilmiah (OECD, 2015). Menurut literasi sains merupakan tujuan utama dari pendidikan sains. Literasi sains tidak hanya mengacu pada pemahaman struktur ilmu pengetahuan dan teknologi melainkan juga memahami sifat ilmu pengetahuan dan teknologi dan hubungan mereka dengan masyarakat. menyatakan bahwa dalam pembelajaran SocioScientific Issues (SSI) mempunyai beberapa manfaat yaitu menumbuhkan literasi sains pada peserta didik sehingga dapat menerapkan pengetahuan sains berbasis bukti dalam kehidupan sehari-hari.

Hal tersebut diperkuat oleh hasil penelitian yang dilakukan oleh Fowler, Zeidler, dan Sadler (dalam Zeidler \& Nichols, 2009, p.54) yang menyatakan bahwa pembelajaran dengan menggunakan konteks SSI dapat meningkatkan sensitivitas moral siswa, sehingga memberikan kontribusi bagi perkembangan moral siswa secara keseluruhan. Menurut mereka, melalui pembelajaran berkonteks Socio-Scientific Issues (SSI) siswa diarahkan untuk menggali dan memperhatikan kehidupan, kesehatan dan kesejahteraan orang lain.

Peningkatan literasi sains sebagai dampak penggunaan konteks SSI juga didukung oleh yang menyatakan pembelajaran berbasis SSI dapat meningkatkan literasi sains dan dapat membantu siswa menjadi warga negara yang bertanggung 
jawab, disebabkan pembelajaran berbasis SSI mempersiapkan siswa untuk mengkaji dan meneliti masalah sosial yang berhubungan dengan sains.

Peningkatan literasi sains siswa sangat berhubungan dan berbanding lurus dengan respon siswa terhadap proses pembelajaran yang telah dilakukan.

Respon siswa merupakan pendapat siswa terhadap ketertarikan, perasaan senang dan keterbaruan, serta kemudahan memahami komponen-komponen yang meliputi buku ajar siswa, kegiatan dalam LKS, suasana belajar, cara guru mengajar dan metode pembelajaran yang digunakan. Respon siswa secara keseluruhan dapat dilihat dalam Gambar 4.

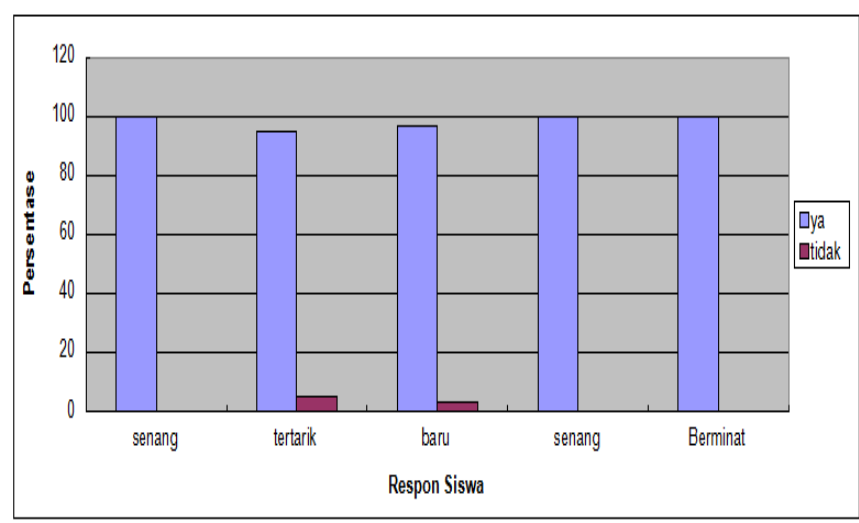

Gambar 4. Respon Mahasiswa terhadap Pembelajaran

Berdasarkan Gambar 4 dapat dikatakan bahwa respon siswa terhadap pembelajaran adalah sangat baik dengan skor rata-rata sebesar $98,33 \%$ artinya siswa menanggapi secara positif terhadap kegiatan belajar mengajar yang telah dilakasanakan. Pengkategorian skor ini mengadaptasi dari Riduwan (2003), yang mengkategorikan persentase respon $81 \%$ - $100 \%$ adalah sangat kuat (sangat positif). Besarnya persentase siswa yang merespon positif pembelajaran ini mengindikasikan bahwa siswa mendukung, merasa senang, dan berminat terhadap pembelajaran berkonteks socio-scientific issues berbantuan media blog.

\section{PENUTUP}

\section{Simpulan}

Berdasarkan hasil analisis data penelitian dan pembahasan dapat disimpulkan sebagai berikut:

1. Keterlaksanaan pembelajaran dengan menerapkan pembelajaran berkonteks socioscientific issues berbantuan media blog pada sub materi zat aditif dalam makanan berada dalam kategori sangat baik dengan penilaian keterlaksanaan pembelajaran pada pertemuan 1, pertemuan 2 dan pertemuan 3 berturut-turut adalah 3,$78 ; 3,95$; dan 3,96.
2. Skor rata-rata kemampuan literasi sains siswa pada pre test 31,78 sedangkan post test 86.02 , ada peningkatan kemampuan literasi sains siswa rata-rata sebesar 54,24.

3. Siswa merespon positif pembelajaran IPA berkonteks socio-scientific issues berbantuan media blog dengan jumlah siswa yang merespon positif sebesar 98,33\%. Ini artinya siswa sangat berminat terhadap pembelajaran berkonteks socio-scientific issues berbantuan media blog.

\section{Saran}

Penelitian ini sebaiknya dikembangkan lebih lanjut untuk menganalisis kesulitan-kesulitan siswa dalam mengerjakan soal literasi sains dan membiasakan soal-soal yang mengacu pada indikator literasi sains sehingga siswa akan terbiasa dan terlatih untuk menyelesaikan soal-soal tersebut.

\section{DAFTAR PUSTAKA}

BSNP. (2010). Penyusunan KTSP Kabupaten/Kota: panduan penyusunan kurikulum tingkat satuan pendidikan jenjang pendidikan dasar dan menengah. Jakarta: Departemen Pendidikan.

DeBoer, G. (2000). Scientific Literacy: Another Loot at Its Historical and Comtemporary Meaning and Its Relationsip to Science Education Reform. Journal of Reseach in Science Teaching,37, 582-601

Heni, T. Agnes. 2008. Langkah Mudah Mengembangkan dan Memanfaatkan Weblog. Yogyakarta: Penerbit Andi.

Herlanti, Y., et.al. 2012. Kualitas Argumentasi pada Diskusi Isu Sosiosaintifik Mikrobiologi Melalui Weblog. Jurnal Pendidikan IPA Indonesia. Vol 1 (2): 168177

Nuangchalerm, Prasart. 2010. Learning outcomes between Socioscientific Issues-Based Learning and Conventional Learning Activities. Journal of Social Sciences 6 (2), 240-243

Nuangchalerm, Prasart. 2010. Engaging Students to Perceive Nature of Science Through Socioscientific Issues-Based Instruction. European Journal of Social Sciences, (13), no. 1, p. 34-37

OECD. (2013). Assesment and Anilitycal Framework mathematicts, reading, Science, Probelm Solving dan Financial LIteracy. s.l: OECD Publising.

OECD. (2015). Assesment and Anilitycal Framework mathematicts, reading, 
Science, Probelm Solving dan Financial LIteracy. s.1: OECD Publising.

Purwanti Widhy H. 2013. Integrative Science Untuk Mewujudkan 21st Century Skills pada Pembelajaran IPA. Prosiding seminar Nasional MIPA UNY. 4 Mei 2013.

Riduwan. (2003). Skala pengukuran variabelvariabel penelitian. Bandung: Alfabeta.

Zo'bi, A.S. (2014). The effect of using socioscientific issues approach in teachingenvironmental issues on improving the students' ability of making approriate decision towards these issues. International Education Studies, 9(8), 113-123.

Zeidler, Dana L., et. al. 2009. Advancing Reflective Judgment through Socioscientific Issues. Journal of Research in Science Education, vol. 46 (1), p.74-101. 